\title{
The Effect of Learner Autonomy Strategy Based On Web Vs Text and Achievement Motivation on Learning Achievement in Entrepreneurship Subject
}

\author{
Syamsul Hidayat ${ }^{1}$, Punaji Setyosari ${ }^{2}$, Sulton $^{3}$, Sihkabuden $^{4}$ \\ Universitas Negeri Malang, Indonesia, Jl. Semarang No. 5
}

\begin{abstract}
This study aimed to examine the effect of web-based learner autonomy strategy vs. learner autonomy text based students' achievement in entrepreneurship subject at SMK Negeri 3 Jember, East Java, Indonesia. It was using a quasi-experimental design nonequivalent control group designs. The data analysis was using analysis of variance (Anova) factorial design $2 \times 2$, it was performed on the tenth grade students in SMK Negeri 3 Jember. They were 91 students as research subjects. The students were divided into two groups: the experimental groups were 47 students and control groups were 44 students. The technique of determining the subject of the research was done randomly. The results showed that (1) there were significantly differences in learning achievement between groups of students who used learner autonomy strategy by using media webbased and the students' group studied independently by using a media-based text, (2) there were significantly differences on learning achievement in entrepreneurship subject and the students who had high motivation achievement and students who had low motivation achievement (3) there was a significant interaction between learner autonomy strategies that used media (web-based vs. text), and students' achievement motivation on learning achievement in entrepreneurship subjects at SMK Negeri 3 Jember.
\end{abstract}

Keywords: Learner autonomy, achievement motivation, and learning achievement.

\section{Introduction}

The development of information and technology was so rapidly. One of the solution can be done to improve student achievement, is to apply the web-based learning or website in students. Web-based learning strategies or website is learning that utilizing the Internet as a tool for learning. In web-based learning, students can access all the information quickly and without limits, both space and time. Forms of matter, exams, quizzes and other educational means can also be implemented into the web and they can be downloaded by students themselves. Another factor that could be expected to give effect in improving student achievement is the achievement motivation. It is self motive against the abilities of students in achieving the standards of competence or the target subjects.

Learner autonomy by Holec (1981) stated that the independent study usually developed over time in school learning, to give more responsibility for students to work or study. In order to learn can be autonomous, independent learners or students should have the motivation to learn independently, learners or students must: a. feeling confident about the decisions taken and acts, b. appreciating value, reflecting learning, c. deciding whether the learning is effective or whether to try another approach. Learner autonomy that is students should have an understanding of their learning; motivation to take responsibility for their learning; and work with teachers to arrange their learning environment (C andy, 1991; Gorman, 1998; Bates and Wilson, 2002 ;. and Perry et al, 2006). Learner autonomy can consist factors that are internal or external to the learner. External elements are the development of a strong relationship between teacher and pupil (Kesten, 1987; Alexander et al, 1992; Boekaerts, 1997; Bates and Wilson, 2002; and Williams, 2003) and the establishment of 'enabling environment' (MacBeath, 1993 ; Gorman, 1998; Williams, 2003). Mayer et al. (2008) also explains that a successful independent study depends on a number of internal factors and external factors. External factors involve the creation of a strong relationship between teachers and students, and the creation of a supportive environment, where ICT can be an important element. Internal factors are skills that must be earned by individuals including cognitive skills, such as memory and attention focus, as well as problem solving skills. Similarly Sorflaten (2002) have confirmed that the characteristics of students who learn independently: (1) do not rely on teachers; (2) can make decisions about their learning; (3) realize the strength and weakness; (4) connect classroom learning with real world; (5) solely on learning strategies; (6) make a plan and set a goal of learning; (7) have the intrinsic motivation to make progress.

Learning activities can be run well, right, and successful, if the student has a learning strategy that can help them to optimize their learning activities. Arends (1997) states that learning strategies refers to behavior and thought processes used by students against what he learned. Furthermore, Slavin (2000) states that learning strategies must correspond to the learning objectives and student characteristics. This view was reinforced by 
Degeng (2001) which states that learning strategies that students use will determine the process and learning outcomes. Based on the statement above, the choice of appropriate learning strategies will foster student learning activities freely, fun, and meaningful for the development of learning outcomes.

Web-based learning strategy is strategy delivery that are packed in a constructive theory, and learning strategy. It is based on student activity student centered. Web-based learning is often expressed as online learning, is an approach to the professional development of teachers and the instructor communicate according to their needs and their time. While textbook-based learning, tapping on the information obtained in the modules and worksheets, as well as focusing more on the intellectual potential of students, so that other capabilities such as talent, moral, aesthetic and individual abilities are ignored. Textbook-based learning is also called traditional learning. Traditional teaching assumes that knowledge is the capture of a series of facts, concepts or laws that are beyond human beings, so that man accustomed to receiving knowledge no effort to develop the skills they have. Strategies Web-based learning is focused on matters as follows: (1) Creation of a fun learning because it is not bound by time, space and place, (2) learning activity centered based on students' needs and interests, (3) giving freedom to students for web-assisted learning activities through the internet, and (4) open and provide the freedom to collaborate both locally and globally to the students in solving the problematic studies.

In this case it also alleged that achievement motivation can improve student achievement. Achievement motivation is defined as a person's tendency to try to achieve success and have a goal orientation, activity success or failure (Atkinson, 1982). McClelland (1987) defines the achievement motivation as motivation that drives individuals to achieve success and aim to succeed in the competition or rivalry with some measure of excellence (standard of excellence). Atkinson (1958) developed a theory of achievement motivation by providing a label as a motive, the probability of success, and the value of the incentive. Motive portrait of individual differences or dispositions learned yet stable and durable, which includes two principal motives of achievement: working experience success (approach motives successes) and fear of failure (failure approach motive). Motive approach assumed success illustrates the expectation or anticipation of the success of the individual, which reflect his capacity to experience pride in achievement (Atkinson, 1964). If a high level of success approaches motive, then the individual will tend to approach and engage in the task of achieving. While the failure avoidance motive describe the capacity of individuals experiencing pubic and humiliation when failure. When achieving in high level of this motive, individuals avoid becoming involved in performing the task. Many studies have shown that the expectation level higher success related to achieving positive behaviors, which include achievement, choice, and persistence (Schunk et al, 2008).

This study aims to examine and analyze (1) differences in learning achievement entrepreneurship subjects among groups of students who get a web-based learner autonomy strategies with text-based (2) differences in learning achievement entrepreneurship subjects among groups of students who have different learning motivation (3) the effect of the interaction between the learning strategies and student achievement motivation towards learning achievement entrepreneurship subjects.

\section{Method}

This study used a quasi-experimental design nonequivalent control group designs. The data analysis was using analysis of variance (Anova) factorial design $2 \times 2$, it was performed on the tenth grade students in SMK Negeri 3 Jember, they were 91 students as research subjects, the students were divided into two groups: the experimental group were 47 students and control groups were 44 students while technique of determining the subject of the research was done randomly.

The research instrument used as a data collection tool in this study consisted of two types, are as follows. (1) The instrument was the learning achievement of academic proficiency test (pretest and posttest) (2) Instrument student achievement motivation was developed by Robinson $(19,91)$. Data analysis technique in this study was using ANOVA technique (analysis of variance) two lanes.

\section{Results And Discussion}

The results will be presented, the first description of the data obtained from the learning achievement of students who learned by using web-based self-learning strategies and text-based. The second data description was achievement motivation on entrepreneurship learning achievement. The results of student entrepreneurship subjects pretest showed that the average pretest scores in the group treated with web-based self-learning strategy is 71.26. In the group of text-based self-learning strategies, the average pretest score was 68 , it can be seen in Table 1 .

Table 1 Testing Experiment Difference Value and Control Group Pretest

\begin{tabular}{|l|l|l|l|l|}
\hline Group & $\mathrm{N}$ & Low & high & mean \\
\hline Experiment & 47 & 60 & 78 & 71.26 \\
\hline Control & 44 & 65 & 75 & 68.86 \\
\hline amount & 91 & 125 & 153 & 140.12 \\
\hline
\end{tabular}

(Source of the data: SPSS 20.0) 
Judging from the two groups learning strategy, it could be seen that the average pretest both treatment groups was almost identical. It showed that both strategies were used entrepreneurial learning achievement of both treatments. It showed that there was no significant difference or no data is distorted or Data outlier.

The results of hypothesis testing on unity tested in this study was the effect of learner autonomy strategy on entrepreneurial learning achievement, Based on the data analysis showed that a significant price was 0.000 ( $\mathrm{p} \leq 0.05$ ), the null hypothesis was rejected so that it could be interpreted as significant differences entrepreneurial learning achievement between groups of students who are taught by the web-based learning and groups of students who are taught by text based learning, were presented in table 2.

Table 2 Results of Factorial Anova tested briefly by a statistical formula SPSS version 20 for Windows.

\begin{tabular}{|l|l|l|l|l|l|l|}
\hline \multicolumn{2}{|l|}{ Tests of Between-Subjects Effects } \\
\hline Dependent Variable: Learning Achievement & Sig. & Partial Eta Squared \\
\hline source & Type III Sum of Squares & Df & mean Square & F &, 000 &, 749 \\
\hline corrected Model & $3184.305^{\text {a }}$ & 3 & 1061.435 & 86.667 &, 000 &, 998 \\
\hline intercept & $466,234.499$ & 1 & $466,234.499$ & 38068.196 &, 000 \\
\hline Strategy & 2951.305 & 1 & 2951.305 & 240.975 &, 000 &, 735 \\
\hline Motivation & 179.727 & 1 & 179.727 & 14.675 &, 000 &, 144 \\
\hline Strategy * Motivation & 51.022 & 1 & 51.022 & 4,166 &, 044 &, 046 \\
\hline Error & 1065.519 & 87 & 12.247 & & & \\
\hline Total & $473,549.000$ & 91 & & & & \\
\hline corrected Total & 4249.824 & 90 & & & & \\
\hline a. R Squared =, 749 (Adjusted R Squared =, 741) & & & \\
\hline
\end{tabular}

The results of this study found that the web-based strategies, the average achievement entrepreneurial study was higher than the mean of the group of students that learned with strategy instructional text by calculated F value of 240.475 with level sig. $0.000<0.05$. Thus it could be said that the implementation of webbased learning was better than text-based learning if it was implemented in vocational schools. This finding was consistent with previous finding Shih \& Gamon (2001) stated that the factor of the advantages which was the convenience factor was supported by competition and high expectations in learning web. But in his research concluded web-based learning was good without being affected by achievement motivation, as well as a background study.

The research result of Hariadi \& Wurijanto (2016) concluded that the web-based learning could improve learning outcomes although in obtaining optimal learning results still need cooperation and learners' blended learning. Hodge et al. (2009) also stated on his findings that the students were motivated to complete more homework using web-based tools instead of the traditional paper-based, with reason web-base tool had the ability to provide instant feedback for the students about the truth of their work and allow them to resend until correct.

Although Day et al. (1997) found no effect on student achievement or attitudes toward web-based instruction. Learning strategies could be applied in vocational schools, but the effectiveness of this strategy still needs to be studied more thoroughly. According to Kevin Kruse (2004) identified two limitations of web-based learning. First, the limitations of human contact will greatly affect learning. Second, the limited multimedia components could be displayed, because it required a large bandwidth. While the implementation of text-based learning, there were some things that could be put forward, among others: (1) teachers did not have constraints in implementing text-based learning. The implementation of text-based learning was commonly practiced; (2) the students read the text, discussion and questions and answers to find meaning from the text; (3) establishing a partnership to develop the values, attitudes and skills. This was done in group; (4) the end of the lesson the students could build independence in the tasks given.

The results of the second hypothesis testing in this study were the effect of achievement motivation on entrepreneurship learning achievement. Based on the data analysis showed that a significant price was 0.000 , ( $p$ $\leq 0.05)$, the null hypothesis was rejected so that it could be interpreted significant differences in achievement entrepreneurial study among groups of students who had high achievement motivation with a group of students who had low motivation.

There were several findings in this study about achievement motivation; there was a significant difference to achievement study entrepreneurship. They were;

First, the findings of this study showed that students who learn with high achievement motivation was significantly superior to the students who studied with low achievement motivation , Posttest score average learning entrepreneurial achievement students that learned with high achievement motivation $=73,36$ and average score learning entrepreneurial achievement students that learned with low achievement motivation = 70.36. So overall, students' learn entrepreneurial achievement that learned with high achievement motivation wan better than low achievement motivation. This finding is in line with Nisa Awan \& Noureen (2011) states that the results showed that achievement motivation is significantly related to academic achievement, although 
gender roles also come into play. Many researchers have concluded that student achievement motivation has a positive effect on their grades and achievement motivation subjects allow them to be more organized in their studies (Abouserie, 1995; Akbaş and Kan, 2007; Tella, 2007). In short, achievement motivation contributed to improving the level of achievement. Therefore, it can be suggested that the motivation has important effects on academic achievement, and is also an important component of the process of education and learning.

Second, students who studied with high achievement motivation were significantly superior to the students who studied with low achievement motivation. Achievement motivation had been defined as the extent to which individuals differ in their need to strive to achieve the award, such as physical satisfaction, praise from others and a sense of personal mastery (Mc Clelland, 1985). Individuals with high achievement motive usually act in a way that will allow them to outperform others, meeting or exceeding some standards of excellence or doing something unusual (Schmidt \& Frieze, 1997). All students were influenced by the need to reach a certain level (Awan et al, 2011). Achievement motivation could be seen as self-determination for success in any activity involved in both the academic work, professional work, sporting events, among others (Tella, 2007). Moula (2010) linking academic achievement motivation and see this as a need or desire to excel in academic work as a motivated person tends to perform well in their exams.

Third, According to Atkinson (1966) the motive for success is determined by three things: (1) the need to be succeeded or need achievement; (2) estimation of a person's success in carrying out specific tasks; and (3) incentives for success, how many people who want to succeed in a particular task. The motive to avoid failure is determined by three the same consideration: (1) the need to avoid failures, such as the need to be achieved on success, (2) estimation of a person, the failure possibility at a particular task; and (3) incentive value of failure in the task, namely, how nice it would fail. According to this theory it was obvious that the group of students who had high achievement motivation would act in a way that allows it to outperform others. O'Connor et al. (1966) found that student achievement-oriented showed greater growth in scholastic achievement and they were more interested in school work when placed in a homogeneous class capabilities. Student-threatening failure showed there were no difference in achievement but it could cause decreasing an interest in school task when placed in the class.

The statistical tests results of interaction between web-based learning and text based learning to learning achievement in students who had high achievement motivation and had low achievement motivation showed the calculated $F$ value of 4.166 with $p=0.044$ smaller than a $=0.05$. The $p$-value was smaller than a means. The hypothesis was accepted. There was an interaction between the learning strategies and students who had high achievement motivation and had low achievement motivation on learning achievement. The results showed that the value of learning achievement on the student were high and students had low achievement motivation on learning by using web-based learning entrepreneurial both of them included in either category. The mean value of learning achievement in high achievement motivation was 79.522 and the value of learning achievement in low achievement motivation was 75.208. Acquisition of learning achievement proved that webbased learning had a positive impact on learning achievement. It showed differences in learning achievement scores on high achievement motivation and low achievement motivation. It can be seen in Figure 1. It showed that the group of students who had high achievement motivation towards entrepreneurial subjects were superior in achieving good entrepreneurial learning web-based learning strategies, as well as in text-based learning.

Figure 1 Interaction between Learner autonomy strategy and achievement motivation

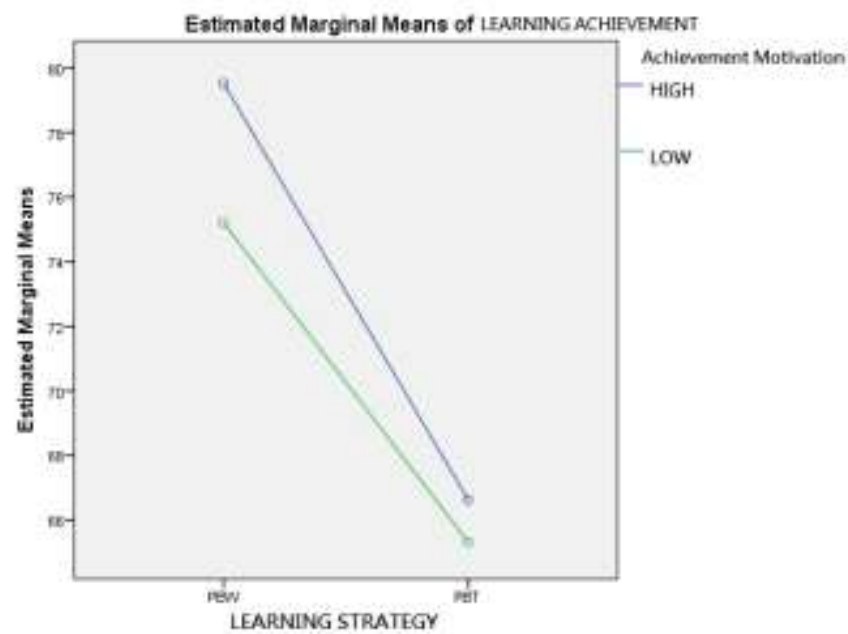


These findings concurred with those Hodge et al. (2009) said the findings that the students were motivated to complete more homework using web-based tools instead of the traditional paper-based, with reason Tool web-base had the ability to provide instant feedback to students about the truth of their work and allow them to resend until correct. Shih \& Gamon (2001) says that the motivation was the only significant factor in web based learning accounts for over a quarter of students' achievement, he also stated that advantages factor was the convenience factor. It was supported by competition and high expectations in learning web. Lokie (2011) states students who learn by using the internet or web-based performance increased but not significantly, because these research students are still working individually in the task.

The findings in this study indicated that in web-based learning strategies application needed to consider student achievement motivation because it let the students work on received assignments from the instructor for their motivation. Another thing was child's ability to operate a computer and the internet were not entirely the same then, it also would affect their performance. Another problem was internet network in their home, because if you relied on the Internet in schools, it was also greatly impede the learning process of students. According to the research Soylu \& Akkoyunlu (2002) says that the different environment if it was not addressed in instructional design process then the students did not show an increase learning achievement. Thus it could be said that the implementation of web-based learning was better than text-based learning if it was implemented in secondary schools Vocational.

\section{Conclusion}

Based on the result and discussion, it can be concluded as follows: 1) entrepreneurial learning achievement between groups of students who were taught by the web-based learning and groups of students who were taught by existing text based learning had significant difference. Students who take the web-based learning strategies was better than students who take the text-based learning, 2) entrepreneurial learning achievement between groups of students who had high achievement motivation and groups of students who had low achievement motivation had significant different. The students who had high achievement motivation was better than the students who had low achievement motivation, 3) There was significant difference on interaction between learning strategy and achievement motivation on learning achievement in the subjects of entrepreneurship. Learning achievements which obtained by the students in high achievement motivation group and low achievement motivation had significant differences. This indicates that the advantages of class experiment in web-based instructional strategies on learning achievement were strongly influenced on achievement motivation.

\section{References}

[1] Abouserie, R. 1995. Self-esteem and achievement motivation as determinants of students' approaches to studying, Studies in Higher Education, 20: 1, 19-26

[2] Akbaş, A., \& Kan, A. 200). Affective Factors That Influence Chemistry Achievement (Motivation and Anxiety) and the Power of These Factors to Predict Chemistry Achievement-II. Journal of Turkish Science Education,Volume 4, Issue 1.

[3] Alexander, R., Rose., J. and Woodhead, C. 1992. Curriculum organization and classroom practice in primary schools. London: Department for Education and Skills.

[4] Arends, R.I, 1997. Classroom Instructional Manageme,. New York: MCGraw-Hill Companies. Inc.

[5] Atkinson, J.W. 1958. Motives in fantasy, action, and society. Princeton, N. J.: D. Van Nostrand

[6] Atkinson, J. W. 1964. Motivational determinants of risk-taking behavior. Psychlogical Review, 359-373.

[7] Atkinson, J. 1982. Motivation and Achievement. Washington, D.C: V.H. Winston and Son

[8] Bates, I. and Wilson, P. (2002). Family and education: supporting independent 1 earning. Learning and Skills Research, 6(1), 3.

[9] Boekaerts, M. 1997. Self-regulated learning: a new concept embraced byresearchers, policy makers, educators, teachers and students. Learning and Instruction, 7(2), 161-86.

[10] Candy, P. 1991. Self-direction for lifelong learning: a comprehensive guide to theory and practice. San Francisco: Jossey-Bass.

[11] Day, T. M., Raven, M., \& Newman, M. E. (1997). The effects of World Wide Web instruction and traditional instruction and learning styles on achievement and changes in student attitude in a technical writing in an agricommunicationcourse. Proceedings of National Agricultural Education Research Meeting (pp. 167-175). Las Vegas, NV.

[12] Degeng, 2001. Tiori Belajar dan Pembelajaran, Malang: Universitas Negeri Malang, Lembaga Pengembangan Pendidikan dan Pembela-jaran (LP3).

[13] Gorman, M. 1998. The 'structured enquiry' is not a contradiction in terms: focused teaching for independent learning. Teaching History, 92, 20-5

[14] Hariadi, B.\& Wurijanto, T. 2016. Influence of Web Based Cooperative Learning Strategy and Achiever Motivation on Student Study Outcome. International Journal of Evaluation and Research in Education (IJERE) Vol.5, No.3, September 2016, pp. 189 199. (Online), (http://files.eric.ed.gov/fulltext/EJ1115394.pdf), diakses tgl 2/2/2017

[15] Hodge, A., Richardson, J.C., \& York.C.S. 2009. The Impact of a Web-based Homework Tool in University Algebra Courses on Student Learning and Strategies. MERLOT Journal of Online Learning and Teaching, Vol. 5, No. 4.

[16] Holec, 1981, Independen Learning, in The Quality Improvement Agency for Lifelong Learning(QIA)2008, (Online), (http://tlp.excellencegatewey. org.uk.tlp/xcurricula/el/assets/document/independent_O.Pdf.). Diakses tgl 5/2/2017

[17] Kesten, C. 1987. Independent learning. Saskatchewan: Saskatchewan Education.

[18] Kruse, Kevin. (2004). Using the Web for Learning: Advantages and Disadvantages, (Online), (http/www.e-learninggurucom/articles/art^Q.hlm), Diakses tgl 28/2/2017.

[19] Lokie, J.M. 2011. Examining Student Achievement and Motivation Using Internet Based Inquiry in The classroom. Public Access Theses and Dissertations from the College of Education and Human Sciences. Paper 102. 
[20] MacBeath, J. 1993. Learning for your self: supported study in Strathclyde schools.Strathclyde: Strathclyde Regional Council.

[21] McClelland, D.C. 1987. Human Motivation. New York: The Press Syndicate of The University of Cahambridge

[22] McClelland, D. C. 1985. Human Motivation. Chicago: Scott Foresman.

[23] Meyer, 2008. What is Independent Learning and What are the Benefids for pupels?; London Departement for Children, School and Families research Report 051, 2008.

[24] Nisa Awan, R.U. \& Noureen, G. 2011. A Study of Relationship between Achievement Motivation, Self Concept and Achievement in English and Mathematics at Secondary Level. International Education Studies Vol. 4, No.3.(Online), (http://citeseerx.ist.psu.edu/viewdoc/download?doi=10.1.1.659.4037\&rep=rep1\&type=pdf), diakses tgl.7/2/2017

[25] O'Connor, P., Atkinson, J. W., \& Horner, M. 1966.Motivational implications of ability grouping in schools. In J. W. Atkinson \& N. T. Feather (Eds.), A theory of achievement motivation. New York: Wiley

[26] Perry, N.E., Phillips, L. and Hutchinson, L. (2006). Mentoring student teachers to support self-regulated learning. Elementary School Journal, 106(3), 237- 254

[27] Robinson, J. P., Shaver, P. R., \& Wrightsman, L. S. (1999). Measures of Personality and Social Psychological Attitudes. San Diego, CA: Academic Press.

[28] Schmidt, Laura C., and Frieze, I. H. 1997. A Mediational Model of Power, Affiliation and Achievement Motives and Product Involvement, Journal of Business and Psychology, Vol. 11, (4), pp. 425-446.

[29] Schunk, D.H., Pintrivh, P.R, \& Meece, j.L.2008. Motivation in Education; Theory, research, and Applications, Third edition.

[30] Shih, C.C. \& Gamon, Yulia. 2001. Web-Based Learning: Relationships Among Student Motivation, Attitude, Learning Styles, And Achievement. Journal of Agricultural Education, Volume42,Issue4.(online),(http://pubs. aged.tamu.edu/jae/pdf/Vol42/4204- 12.pdf).Diakses tgl 3/2/2017

[31] Slavin, Robert, E.,2000. Educational Psycologycal: Theory and Praktice, $6^{\text {th }}$ Edition, Boston: Allyn \& Bacon.

[32] Sorflaten Robin, 2002. Independent Learning in Your Classroom, Zayed University, UAE.

[33] Soylu, M.Y.\&Akkoyunlu, B.2002. The Effect of Learning styles on Achievement in Different learning environments.The Turkish Online Journal of Educational Technology - TOJET: 1303-6521 volume 8 Issue 4 Article 4

[34] Tella, A. 2007. The impact of motivation on student's academic achievement and learning outcomes inmathematicsamong secondary school students in Nigeria. Eurasia Journal of Mathematics, Science \& Technology Education, 3(2), 154

[35] Williams, J. 2003. Promoting independent learning in the primary classroom. Buckingham: OUP. 